\title{
Good Governance Sebagai Instrumen Kerja Sama Pembangunan Indonesia- Jerman di Yogyakarta
}

\section{Demeiati Nur Kusumaningrum}

Jurusan Ilmu Hubungan Internasional, Universitas Muhammadiyah Malang

Kampus Telogo Mas 246, Malang, 65144

Email: dn.kusumaningrum@yahoo.com

\begin{abstract}
This research explains the relationship between development cooperation and foreign assistance mechanism. Structural adjustment programs (SAP) required to developing countries for the sake of foreign aid tends to transform into global norm-good governance. Legitimate governance aimed to run accountability, transparency, responsiveness, equity and inclusive, effectiveness and efficiency, rule of law, participatory and consensusoriented. Good governance is realized to strategic partnership of Provincial Government of Yogyakarta and the German Government in the area of administrative reform in 2008. It describes the norm empowerment and elite learning mechanism of good governance at the international structure, domestic-Indonesia, and local-Yogyakarta.

Keywords: Good Governance, Norm Empowerment

Abstrak

Penelitian ini menjelaskan hubungan antara kerjasama pembangunan dan mekanisme bantuan luar negeri. Program Penyesuaian Struktural (SAP) diperlukan negara-negara berkembang demi mendapatkan bantuan luar negeri cenderung berubah menjadi norma global, Good Governance. Pemerintahan diharapkan agar berjalan dengan akuntabilitas, transparansi, tanggap, wajar dan inklusif, efektif dan efisien, supremasi hukum, partisipatif, dan berorientasi pada musyawarah. Good Governance diwujudkan kemitraan strategis Pemerintah Provinsi Yogyakarta dan Pemerintah Jerman di bidang reformasi administrasi pada tahun 2008. Ini menggambarkan pemberdayaan norma dan mekanisme belajar elit Good Governance di struktur internasional , domestik - Indonesia , dan lokal - Yogyakarta.

Kata Kunci : Good Governance, Pemberdayaan norma.
\end{abstract}

\section{PENDAHULUAN}

Jerman memberikan bantuan teknis kepada Pemerintah Provinsi Yogyakarta untuk bidang desentralisasi tahun 2008. Bantuan teknis merupakan salah satu bentuk bantuan luar negeri yang dirancang dengan tujuan menyebarkan pengetahuan dan keahlian -knowledge transfer (Holsti, 1988: 249). Pemerintah Jerman melalui staf ahlinya menawarkan programprogram peningkatan kualitas kinerja birokrasi pemerintahan daerah dalam kerangka kerja good governance. Tawaran dari Pemerintah Jerman tersebut disambut sangat baik oleh Gubernur DIY melalui Sekretaris Daerahnya dan kemudian kerja sama ini ditindaklanjuti sebagai salah satu upaya reformasi administrasi publik. Pada tahun 2010 staf ahli Jerman mendirikan Center for Good Governance (CGG) untuk memudahkan kinerjanya di Yogyakarta. Dalam masa tugasnya membantu Pemprov DIY mewujudkan tata pemerintahan yang baik, Direktur CGG menjalin kerja sama dengan berbagai elemen masyarakat sipil, tenaga profesional, lembaga pendidikan maupun institusi internasional.

Penelitian ini beranjak dari fenomena di mana negara-negara begitu antusias dengan kemitraan internasional dalam isu good governance. Mengapa good 
governance menjadi salah satu konsep pemerintahan yang diminati saat ini? Apa yang menjadi latar belakang politik kerja sama Jerman dan Indonesia? serta apa yang mendasari kebijakan Pemprov DIY mewujudkan reformasi administrasi publik? Oleh sebab itu, tulisan ini akan mencoba menganalisis dari perspektif Indonesia tentang bagaimana good governance dinternalisasikan dari lingkup internasional hingga di tingkat daerah.

Melalui sudut pandang konstruktivis tentang konsep 'norm empowernment', penulis memahami kemitraan Indonesia-Jerman di Yogyakarta adalah; 1.) implikasi kosmopolitanisme good governance oleh masyarakat transnasional, 2.) keberlanjutan dari restrukturisasi Indonesia pasca krisis Orde Baru, 3.) bentuk identifikasi Indonesia sebagai negara demokrasi yang mendukung komitmen Millenium Development Goals (MDGs), dan 4.) implementasi good governance adalah bagian dari semangat politik pembangunan Jerman di Indonesia.

\section{PEMBAHASAN}

KONSTRUKTIVISME CHECKEL: INTERNALISASI NORMA MELALUI MEKANISME PEMBELAJARAN ELIT

Good governance sebagai norma internasional dapat diterima di tingkat lokal dipahami sebagai mekanisme pembelajaran elit (elite learning mechanism). Jeffrey $\mathrm{T}$. Checkel (1997) dalam "International Norms and Domestic Politics: Bridging the RationalistConstructivist Divide" menggambarkan bagaimana norma internasional diadopsi sebagai sebuah nilai-nilai atau gagasan yang bersesuaian dengan apa yang dipahami oleh elit pembuat kebijakan. Hal ini menunjukkan adanya interpretasi subjektif terhadap struktur internasional yang selaras dengan identitas dan kepentingan pembuat kebijakan. Norma internasional diinternalisasi sebagai logika kepantasan dari pada sesuatu yang dipaksakan. Sehingga, konstruktivisme Checkel ini menjembatani pemikiran liberal-rasionalis bahwa struktur intersubjektif sama pentingnya dengan struktur material (Moravcsik, 1995; Cortell and Davis, 1996; Finnemore, 1996; Katzeinstein, 1996).

Adapun parameter untuk menganalisis 'norm empowerment' adalah adanya perubahan kebijakan di dalam negeri (domestic political attention/debate) dan rezim pendukungnya (regime persistence/maintenance). Perubahan kebijakan tersebut merupakan respon dari pengaruh aktor non-negara atau jaringan-jaringan pembuat kebijakan yang mendukung berlakunya norma internasional tersebut. Seperti yang pernah disampaikan oleh Finnemore (1996) dan Katzenstein (1996), dalam prosesnya pengaruh dari berbagai aktor mampu mengubah persepsi para elit pembuat kebijakan yang kemudian menginterpretasikan norma tersebut sebagai penggambaran identitas dan kepentingannya. 'Elite learning mechanism' dapat terjadi dalam studi kasus Indonesia karena kategorisasi struktur politik domestiknya yang korporatis (Checkel, 1997: 479). Hal tersebut dikarenakan pembuatan kebijakan di Indonesia masih menjembatani kepentingan masyarakat dan elit politik (negara) yang menggambarkan proses internalisasi norma (Checkel, 1997:479). ${ }^{1}$

\section{INSTRUMEN KERJA SAMA PEMBANGUNAN INTERNASIONAL: SAP VS. GOOD GOVERNANCE}

Good governance mulai berkembang menjadi norma internasional sebagai hasil dari difusi globalisasi. Good governance merupakan nilai-nilai atau gagasan yang mengemuka pasca Perang Dingin dan menyebar sebagai instrumen kerja sama pembangunan internasional (Baylish and Smith, 2005:326-327). ${ }^{2}$ Konsep good governanace seolah menggeser ketakutan negara-negara berkembang terhadap konsekuensi mekanisme bantuan luar negeri yang dikenal dengan structural adjustment program-SAP. Program penyesuaian struktural (SAP) pada umumnya bersifat mutlak sebagai prasyarat dicairkannya pinjaman luar negeri. SAP sering menjadi polemik internal di negara-negara berkembang. SAP dipandang sebagai mekanisme yang menimbulkan dilema antara kebutuhan dan kemandirian.

Pro dan kontra terhadap pinjaman luar negeri pernah menjadi pengalaman Indonesia pada akhir tahun 1990-an. Pemerintah Orde Baru memperoleh dana pinjaman dari IMF ketika terjadi krisis ekonomi 
Asia tahun 1997. Pinjaman IMF diyakini sebagai strategi untuk menyelamatkan perekonomian negara pada masa itu. Sementara, SAP yang disyaratkan IMF pada akhirnya meliberalisasi ekonomi-politik Indonesia dan menimbulkan masalah-masalah sosial baru (Rais 2008; Winarno 2010).

Para akademisi hubungan internasional seperti Winarno (2010) dan Rais (2008) berpendapat bahwa liberalisasi hampir semua bidang kehidupan di Indonesia nyatanya tidak dapat menjamin kualitas kesejahteraan masyarakat. Peran pemerintah dalam memfasilitasi kebutuhan dasar masyarakat semakin kecil karena adanya pembatasan terhadap subsidi bahan bakar, pangan, pendidikan, dan kesehatan. Otoritas politik-ekonomi negara sebagian besar telah diambil alih oleh kehendak pasar (market-capitalism power). Hal itu dapat diamati sebagai paradoks kehidupan, di mana jauh sekali kualitas kesejahteraan antara kaum pemodal dan buruh di kota-kota besar. Sehingga, liberalisasi ekonomi-politik yang direkomendasikan oleh negara-negara donor tidak dapat menanggulangi fenomena ketimpangan sosial di Indonesia.

Sementara, upaya pemerintah meningkatkan efektifitas pijaman luar negeri pun masih diragukan. Menurut Rais (2008) dana pinjaman luar negeri di Indonesia justru memunculkan 'state capture corruption' dimana pemanfaatannya hanya dinikmati oleh korporatokrasi atau elit-elit birokrasi pendukungnya. Oleh sebab itu, negara berkembang seolah 'was-was' terhadap wacana pinjaman luar negeri bagi pembangunan karena implikasi dari prasyarat SAP yang cenderung dilematis.

Adapun memasuki era 90-an, isu pembangunan dan pinjaman luar negeri mengadopsi sebuah konsep baru yang mengobati ketakutan negara-negara berkembang terhadap mekanisme SAP. Konsep tersebut merupakan prinsip-prinsip terbaik tentang tata pemerintahan yang populer dengan istilah 'good governance'. Berkembangnya konsep good governance berkaitan dengan respon organisasi-organisasi internasional dalam membangun kembali relasi politik-ekonomi dunia.
Dalam perspektif politik, pasca Perang Dingin negara-negara ingin melepaskan diri dari situasi pertikaian yang sarat dengan fragmentasi politik BaratTimur. Strategi pembangunan diarahkan untuk menciptakan tatanan dunia yang lebih harmonis melalui kerja sama. Dalam konteks ekonomi, kegiatan industrialisasi dan intensifikasi buruh sebagai motor pertumbuhan (growth) belum dapat mengatasi kemiskinan. Sehingga, perlu dibentuk kerja sama pembangunan internasional yang berorientasi pada kesejahteraan bersama (common prosperity).

Argumen tersebut dipertajam oleh protes kaum environmentalist terhadap tanggung jawab kelestarian lingkungan. Eksploitasi sumber daya alam yang radikal demi mencapai keuntungan ekonomi menyebabkan kehancuran ekologi. Jika tidak ditanggulangi, hal ini akan mendorong kematian makhluk hidup termasuk manusia di masa depan. Sehingga, pendekatan pembangunan berkelanjutan (sustainable development) direkomendasikan sebagai alternatif kebijakan pembangunan. Ketiga interpretasi masyarakat internasional terhadap situasi dunia pada waktu itu mendorong didiskusikannya kembali 'negara dan pemerintahan' sebagai isu sentral.

\section{KOSMOPOLITANISME GOOD GOVERNANCE: ORGANISASI INTERNASIONAL SEBAGAI AGEN}

Konseptualisais good governance dibangun melalui diskusi global dan komunikasi politik negara-negara dalam aktifitas organisasi internasional. Negara-negara secara berkesinambungan mengupayakan strategi maupun kebijakan untuk mengatasi masalah kemiskinan. Adapun UNDP (1997) mendefinisikan 'governance' sebagai "penggunaan kekuasaan politik, ekonomi, dan administratif dalam mengelola berbagai urusan negara pada semua level. Pemerintahan terdiri dari mekanisme, proses, dan institusi yang kompleks di mana warga negara dan kelompok masyarakat dapat mengartikulasikan kepentingan mereka, memediasi berbagai perbedaan, serta mendapatkan hak dan melaksanakan kewajibannya". UNDP mengartikan 'good governance' sebagai 'democratic governance'.

Pemerintahan yang baik adalah pemerintahan 
demokratis. Hal itu mencakup bagaimana seluruh masyarakat dapat terlibat dalam pembuatan keputusan politik yang mempengaruhi seluruh aspek kehidupannya. Peningkatan partisipasi masyarakat dalam pembuatan kebijakan pemerintahan dan ekonomi akan mendorong alokasi sumber daya dan pelayanan publik yang lebih responsif terhadap kebutuhan masyarakat. Selain itu, pemerintahan yang demokratis mampu memberi kepastian hukum, trasparansi kebijakan, dan strategi pembangunan berkelanjutan sehingga dapat mewujudkan kesejahteraan masyarakat. Individu akan merasa hakhak kepemilikan/ propertinya dilindungi, sektor swasta maupun pengusaha dapat membangun bisnisnya dengan lancar dan menciptakan lapangan pekerjaan yang lebih luas. Sehingga, interaksi yang harmonis antara 'state', 'civil society', dan 'private sector' inilah yang mendukung bekerjanya prinsip-prinsip good governance. (UNDP 1997)

Sementara, Bank Dunia dan IMF memahami masalah kemiskinan sebagai kegagalan pemerintahan. Pemerintahan tidak memiliki kapasitas dalam mengembangkan strategi pembangunan yang oleh Caiden (1991) disebut mengidap penyakit bureaupathologies (Keban, 2000)3. Pemerintahan -baik birokrasi maupun hasil kebijakannya- tidak dapat menjalankan fungsinya secara optimal. Praktik korupsi dan penyelahgunaan wewenang menjadi budaya. Krisis pemerintahan kurang menjamin efektifitas pemanfaatan pinjaman luar negeri bagi pembangunan yang pada akhirnya menghasilkan fenomena kemiskinan. Sehingga, good governance di negara penerima pinjaman penting untuk diterapkan sebagai tolak ukur performa pembangunan (Nanda, 2006:269. 270). ${ }^{4}$

Publikasi Bank Dunia pada tahun 1998 berjudul "Assessing Aid-what works, what doesn't and why?" menggambarkan minat institusi tersebut untuk mengkonsentrasikan bantuan luar negeri kepada negara-negara yang menunjukkan kesungguhannya dalam menjamin efektifitas pemanfaatan bantuan luar negeri (Folke dan Nielsen, 2006: 7-8). Kebijakan ini didukung oleh penelitian Alesina dan Dollar (2000) yang berjudul "Who Gives Foreign Aid to Whom and

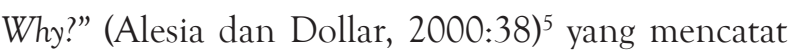
adanya kenaikan tahap pemberian bantuan luar negeri sebesar $75 \%$ selama proses demokratisasi di negaranegara penerima.

Bank Dunia dan IMF berpendapat bahwa pemerintahan yang baik adalah pemerintahan yang efektif. Negara dapat mencapai efektifitas penyelenggaraan pemerintahan apabila melaksanakan reformasi manajemen publik (New Public ManagementNPM) yang mengadopsi praktik manajemen swasta (Hood, 1998). Hal ini menyangkut ideologi dan mekanisme tertentu. Ideologi berkaitan dengan bagaimana pemerintahan menjadi lebih kompetitif dalam performanya, responsif dalam menghadapi tantangan dari dalam maupun luar negeri, dan efisien dalam pengelolaan sumber daya. Sementara, mekanisme berkaitan dengan bagaimana profesionalitas birokrasi, pemanfaatan teknologi, dan sistem pemerintahan yang dapat menjamin berfungsinya pasar secara sehat. (Hansen, et.al., 2002; Kimmet, 2004; Syakrani dan Syahriani, 2009; Sulistiyani, 2011). NPM mendorong akuntabilitas pemerintahan terhadap efektifitas pelayanan publik, transparansi pemerintah dalam proyek-proyek pembangunan, baik masalah tender, penganggaran, pengeluaran, maupun pemanfaatan bantuan luar negeri.

Dengan demikian, konsep good governance dapat dipahami sebagai seperangkat norma, mekanisme, atau nilai-nilai yang dibangun oleh para aktor hubungan internasional dan diinternalisasi menjadi sebuah klaim kebenaran atas bentuk tata pemerintahan terbaik. Good governance (UNESCAP 2011) diyakini sebagai tata kelola pemerintahan yang baik di mana memenuhi prinsip-prinsip: akuntabilitas, transparansi, responsivitas, kesamaan dan keadilan, efektivitas dan efisiensi, kepastian hukum, partisipatif, dan representatif/ berorientasi konsensus.

\section{GOOD GOVERNANCE SEBAGAI INSTRUMEN PENCAPAIAN MDGS DAN KESUKSESAN OTONOMI DAERAH \\ Internalisasi good governance di Indonesia mencakup}


empat area besar yaitu: adanya penguatan institusi yang demokratis, peningkatan pelayanan publik, penegakan hukum, dan pemberantasan korupsi. Pasca pemerintahan Orde Baru Indonesia mengimplementasikan prinsip-prinsip good governance melalui kebijakan-kebijakan yang menaruh perhatian pada kebebasan informasi dan pers, penguatan fungsi check and balance oleh parlemen, peningkatan partisipasi publik dalam politik, pemberantasan korupsi, dan desentralisasi/ otonomi daerah.

Berbagai elemen masyarakat di Indonesia bergolak, di mana kondisi sosial ekonomi mengalami kemerosotan akibat krisis moneter Asia tahun 1997. Wacana demokrasi muncul sebagai koreksi terhadap kepemimpinan Presiden Soeharto yang dipandang kurang efektif. Sistem pemerintahan yang sentralistik diyakini memberikan celah terhadap penyalahgunaan kekuasaan. Proses pembuatan kebijakan banyak menguntungkan elit-elit pendukung Orde Baru. Selain itu, hasil-hasil pembangunan belum dirasakan secara menyeluruh oleh rakyat Indonesia. Pertumbuhan ekonomi masih terpusat di pulau Jawa dan Bali. Masyarakat di luar kedua wilayah tersebut masih terkendala dengan masalah distribusi pendapatan. Sehingga, kemiskinan dan keterbelakangan menjadi kritik atas kebijakan pembangunan yang dicanangkan Presiden Soeharto.

Jargon-jargon demokrasi semakin meluas dalam diskusi berbagai elemen masyarakat. Masyarakat menilai tekanan ekonomi yang mereka rasakan adalah akibat dari kesalahan tata kelola pemerintahan. Selama kepemimpinan Orde Baru, alokasi sumber daya sebagian besar dipusatkan ke Ibukota. Meskipun beberapa provinsi memiliki kekayaan alam sangat potensial, nyatanya kesejahteraan tidak dirasakan merata hingga ke daerah. Korupsi, kolusi, dan nepotisme menjadi fenomena yang melekat pada periode tersebut mengingat kesejahteraan hanya dinikmati oleh elit-elit pemegang kekuasaan.

Pasca berakhirnya kepemimpinan Orde Baru, pemerintahan Presiden B.J. Habibie mengevaluasi kebijakan otonomi daerah di Indonesia dengan dikeluarkannya UU No. 22 Tahun 1999 Tentang
Pemerintahan Daerah dan UU No. 25 Tahun 1999

Tentang Perimbangan Keuangan Pusat-Daerah. Melalui ketetapan tersebut diharapkan pemerintah daerah dapat melaksanakan fungsinya secara otonom untuk mengatur rumah tangganya sendiri dan mengelola potensi sumber daya daerah bagi sebesar-besarnya kemakmuran masyarakat. Dalam hal ini, pembagian wewenang dari pusat ditujukan untuk mencapai kepentingan nasional dan tidak keluar dari konteks Negara Kesatuan Republik Indonesia (Dwiyanto, dkk, 2003: 18-19). Norma good governance diinternalisasi di Indonesia sejak era Reformasi dan diperkuat dengan kebijakan otonomi daerah.

Sementara, kebijakan otonomi daerah terus digulirkan dari tahun ke tahun dan mengalami evaluasi pada masing-masing kepemimpinan. Salah satunya pada pemerintahan Presiden Susilo Bambang Yudhoyono, kebijakan otonomi daerah diperkuat melalui Undang-Undang No. 32 Tahun 2004. Pemerintahan daerah yang dimaksud dalam ketetapan ini menjalankan otonomi seluas-luasnya, kecuali urusan pemerintahan yang menjadi urusan Pemerintah, dengan tujuan meningkatkan kesejahteraan masyarakat, pelayanan umum, dan daya saing daerah. Oleh sebab itu, masing-masing pemerintahan sub-nasional mulai berbenah diri dan mengimplementasikan kebijakan otonomi daerah ini dengan paradigma pelayanan publik untuk mencapai kesejahteraan masyarakat. Dengan keleluasaan dan kemandirian yang diamanatkan dalam UU No 32/ 2004, Pemerintah Daerah mendorong efektifitas kerja sama baik secara internal maupun eksternal demi menyukseskan program-program pembangunan nasional.

Idealisme kesejahteraan global yang berkeadilan diinternalisasikan dalam bentuk program-program kerja sama dalam menanggulangi kemiskinan. PBB menggerakkan kesadaran negara-negara akan cita-cita pembangunan internasional dengan disepakatinya Deklarasi Milenium (MDGs) tahun 2000. MDGs merupakan komitmen negara-negara untuk mengutamakan aspek kesejahteraan bagi masyarakatnya dengan usaha-usaha memberantas kemiskinan dan 
kelaparan ekstrem, memenuhi pendidikan dasar, mendorong kesetaraan gender dan pemberdayaan perempuan, mengurangi angka mortalitas anak, meningkatkan kesehatan ibu, memberantas HIV/ AIDS, malaria dan penyakit lainnya, mengupayakan kelestarian lingkungan hidup, dan mengembangkan kemitraan global untuk pembangunan.

MDGs lahir sebagai respon negara-negara terhadap masalah-masalah di mana; setengah dari populasi manusia yang berada di negara-negara sedang berkembang (NSB) mengalami kelaparan, 113 juta anak-anak usia sekolah belum mendapat pendidikan yang layak, tingginya tingkat buta huruf yang dialami perempuan, kesempatan kerja yang kecil bagi perempuan dibandingkan laki-laki, tingginya resiko ibu meninggal dalam persalinan, penyebaran penyakit AIDS, kerusakan lingkungan, dan kendala kinerja pemerintah yang cukup besar terkait dengan programprogram pembangunan nasional. Oleh sebab itu, MDGs diyakini sebagai visi global untuk memperbaiki kualitas kehidupan masyarakat (UNDP). MDGs diimplementasikan sebagai salah satu program 28 institusi internasional yang menjadi partner dalam pencapaian target-target pembangunan termasuk Bank Dunia, IMF, dan WTO (UN 2010)6. Dalam hal ini kerangka kerja good governance ditekankan sebagai sebuah instrumen bagi terpenuhinya target-target MDGs.

MDGs menggambarkan perubahan paradigma pembangunan di mana individu merupakan modal pembangunan. Komitmen MDGs mendorong pemerintah untuk memfasilitasi masyarakat dengan program-program pemberdayaan dan jaminan kesejahteraan sosial. Dengan demikian, seluruh warga negara dapat menjadi motor penggerak pertumbuhan ekonomi, memiliki kapabilitas untuk mengawasi jalannya pemerintahan, dan sekaligus dapat menikmati hasil-hasil pembangunan secara berkeadilan.

POLITIK PEMBANGUNAN JERMAN-INDONESIA: KERJA SAMA DALAM MEMBANGUN KAPASITAS SUB-NASIONAL DI ERA GLOBALISASI

Kemitraan pemerintah Jerman dan Pemprov DIY di
Yogyakarta dalam bidang reformasi administrasi publik dipengaruhi oleh beberapa faktor yaitu: 1.) menguatnya gelombang demokratisasi ketiga, 2.) kemakmuran bersama sebagai tujuan politik pembangunan, dan 3.) mengemukanya klaim moral atas relasi politik-ekonomi dunia.

Gelombang demokratisasi ketiga sekitar tahun 1974-1990 menandai bergeraknya struktur masyarakat internasional kepada bentuk pemerintahan yang lebih diminati. Negara-negara mengalami transisi pemerintahan dan mulai menerima ide-ide demokrasi sebagai wujud penghargaan nilai-nilai kemanusiaan. Teori klasik demokrasi yang pernah dikemukakan Joseph Schumpeter (1942) mendefinisikan demokrasi sebagai 'the will of the people'. Demokrasi merupakan fitrah manusia yang memiliki tujuan bersama dalam kebaikan- 'the common good' (Huntington, 1990: 6). Negara-negara industri maju mengobarkan semangat demokrasi dan menyebarkan pemikiran bahwa implementasi nilai-nilai demokrasi dapat menjamin tatanan dunia yang lebih damai (Democratic Peace Theory). Utopianisme demokrasi mendorong peran aktor-aktor sentral - AS dan Eropa- untuk menginterpretasikan identitasnya sebagai pengawal demokratisasi di seluruh dunia. Pemahaman ini diimplementasikan melalui partisipasi aktif dalam pembentukan organisasi-organisasi internasional di bidang ekonomi-politik seperti OECD, UNDP, Bank Dunia, IMF, dan WTO.

Organisasi-organisasi internasional memiliki kesalinghubungan dalam mempenetrasikan prinsipprinsip good governance sebagai legitimate conduct. Prinsip-prinsip good governance dikonstruksi sebagai norma global melalui kompleksitas kesepakatan kerja sama pembangunan internasional. Good governance diyakini sebagai institusi yang dapat menjamin efektifitas pinjaman luar negeri. Oleh sebab itu, reformasi tata pemerintahan dipromosikan sebagai upaya melembagakan prinsip-prinsip good governace.

Konsep good governance diakui berkaitan dengan aspek legitimasi pemerintah. Implementasi good governance mendorong tercapainya efektifitas penyelenggaraan pemerintahan. Pemerintahan yang 
efektif menjadi kunci kesuksesan tercapainya targettarget pembangunan. Oleh sebab itu, negara-negara maju menyebarkan pemahaman ini seiring dengan prasyarat kondisional kinerja program-program kerja sama pembangunan di negara-negara berkembang.

Lebih jauh, ketimpangan sosial dan kemiskinan dipahami sebagai implikasi dari kegagalan pemerintahan dalam merespon liberalisasi ekonomipolitik internasional. Oleh sebab itu, negara-negara perlu memperbaiki kinerja pemerintahan agar mampu beradaptasi dengan berbagai perubahan yang sangat cepat di era globalisasi ini. Kerja sama institusional baik secara internal maupun internasional perlu ditingkatkan dalam rangka menghadapi tantangantantangan pembangunan. Negara-negara maju cenderung memposisikan dirinya sebagai mitra strategis negara berkembang dalam menyukseskan proyek-proyek MDGs.

Negara maju mulai meyakini adanya tanggung jawab moral mereka terhadap pemerataan distribusi pendapatan di dunia. Negara-negara maju mulai mengidentifikasi dirinya sebagai negara demokratis yang perlu menjunjung tinggi nilai-nilai kemanusiaan. Sejak penerbitan Human Development Report tahun 1994 oleh UNDP, masyarakat internasional sepakat untuk mengalokasikan 20 persen pendapatannya untuk membantu mewujudkan kesejahteraan bagi wilayah dunia lain yang kurang beruntung. Sehingga, kemiskinan dan ketimpangan sosial tidak lagi menjadi masalah politik-ekonomi tetapi juga masalah kemanusiaan.

Pemerintah sebagai institusi yang memiliki otoritas merumuskan kebijakan perlu sigap dalam merespon fenomena kemiskinan. Kemitraan strategis MDGs sebagai salah satu contoh menuntut pihak-pihak yang berkepentingan untuk berkomitmen penuh terhadap kesejahteraan masyarakat, profesional dalam kinerja, bersih dan bertanggungjawab dalam pengelolaan anggaran pembangunan. Dengan demikian, sumber daya pembangunan dapat dimanfaatkan sebesarbesarnya bagi kemajuan bangsa.

Adapun Jerman sebagai salah satu negara terkemuka di Eropa turut berpartisipasi dalam membangun prinsip-prinsip good governance di negara-negara berkembang. Sejak 2007 pemerintah Jerman memusatkan perhatiannya pada tiga tema utama bagi program kerja sama pembangunan dengan Indonesia, yaitu: pengembangan sektor swasta, desentralisasi/good governance dan perubahan iklim. Dengan bantuan yang keseluruhan mencapai sekitar tiga milyar Euro, Jerman bagi Indonesia merupakan mitra bilateral keempat terbesar dalam bidang kerja sama pembangunan. ${ }^{?}$

Politik pembangunan Jerman menitik beratkan pada perbaikan kondisi ekonomi negara mitra dengan memaksimalkan partisipasi semua elemen masyarakat. Jerman meyakini bahwa pembangunan perlu dilaksanakan secara berkelanjutan (suistainable development) dengan memperhitungkan potensi-potensi domestik baik sumber daya alam maupun sumber daya manusianya. Oleh sebab itu, Jerman mendorong pertumbuhan ekonomi negara mitra pembangunan dengan mempertimbangkan keseimbangan ekologi dan keadilan sosial. Jerman dan Indonesia sepakat untuk memperkuat kerja sama dalam bidang ekonomi, perdagangan dan investasi. Kedua negara menghidupkan kembali "Forum Ekonomi Jerman Indonesia" bertepatan dengan pertemuan Presiden Susilo Bambang Yudhoyono dan Kanselir Jerman Angela Merkel pada Desember 2009.

Menurut Wakil Menteri Negara Perencanaan Pembangunan Nasional/Kepala Bappenas Lukita D.Tuwo, Jerman memberikan hibah sebesar US $\$ 37,5$ juta atau setara - 26,9 juta ke Indonesia dalam bentuk bantuan teknis. Komitmen dana hibah ini adalah hasil kunjungan Presiden Susilo Bambang Yudhoyono akhir tahun 2009 lalu ke Jerman. Pencairan dana untuk beberapa proyek ini dilakukan secara bertahap per proyek mulai 2010. Hibah tersebut dialokasikan untuk proyek perubahan iklim di bidang lingkungan hidup dan kehutanan termasuk pengolahan sampah ramah lingkungan sebesar • 3,5 juta, proyek pengembangan sektor swasta berupa program pelatihan kejuruan senilai • 9,7 juta, dan proyek pembangunan kapasitas sumber daya manusia (SDM) untuk mendukung desentralisasi sebesar $\bullet 8$ juta. Selain itu, pemerintah Jerman juga memberikan bantuan penelitian geologi 
dan mitigasi bencana di Aceh sebesar -3 juta, riset kebijakan dan formulasi sektor kesehatan senilai $\mathbf{B}$ juta, dan bantuan pengembangan sistem perlindungan jaminan sosial sebesar $\bullet 2$ juta, serta program pengembangan sumber daya air di Nusa Tenggara Timur dan Nusa Tenggara Barat sebanyak - 3 juta. Bantuan teknis Jerman tersebut diberikan tidak hanya dalam bentuk dana cair tetapi juga tenaga ahli atau konsultan Jerman dan program-program capacity buiding seperti memberangkatkan orang untuk mengikuti pelatihan di Jerman (tender-indonesia.com 2010).

Jerman merupakan negara donor yang mendukung efektifitas bantuan luar negeri bagi pembangunan. Untuk itu, pemerintah Jerman yang tergabung dalam konsorsium donor multilateral mendukung implementasi good governance di negara mitra sesuai dengan apa yang telah disepakati dalam Deklarasi Paris 2005 dan Accra Agenda for Action 2008.

Bagaimanapun bantuan luar negeri akan dapat dimanfaatkan secara efektif dan bertanggungjawab apabila negara mitra berkomitmen untuk menciptakan tata kelola pemerintahan yang baik. Tujuan politik pembangunan internasional dalam rangka mewujudkan kesejahteraan masyarakat dapat dicapai jika pemerintah negara mitra memiliki visi dan pemahaman yang sama. Sehingga, kerja sama pembangunan internasional tidak hanya berkaitan dengan bagaimana memberikan kepercayaan namun juga manfaat yang nyata bagi warga Negara. Oleh sebab itu, Jerman mendukung kebijakan reformasi pelayanan publik di Yogyakarta sebagai wujud implementasi good governance di tingkat pemerintahan daerah.

\section{KESIMPULAN}

Mengutip pemikiran William D. Coplin (1992: 301-4), kerja sama internasional tidak dapat dipisahkan dari tujuan politisnya. Politik kerja sama internasional meliputi bagaimana birokrat (anggota pemerintahan) saling berurusan satu dengan yang lainnya di samping interaksinya dengan aktor non pemerintah yang bersifat saling mempengaruhi dalam tindakannya. Hal itu juga berbasis pada definisi politik
Lasswell ${ }^{8}$ (1958) tentang penentuan siapa mendapat apa, kapan, dan bagaimana (who gets what, when, dan how). Kerja sama internasional dilaksanakan atas dasar kepercayaan masing-masing pihak terhadap aspek yang menjadi fokus kerja sama.

Pergeseran paradigma pembangunan dan kesejahteraan dari masalah nasional menjadi isu internasional adalah implikasi dari globalisasi. Kompleksitas interaksi yang bertujuan untuk mencari pemecahan kolektif inilah yang digambarkan sebagai dinamika kerja sama internasional. Visi tersebut memuncak dengan disepakatinya Deklarasi Milenium 2000. Dalam konteks mengejar target pembangunan internasional, negara tidak mungkin memenuhi kebutuhannya sendiri. Bagaimanapun, permasalahan yang terjadi pada tingkat domestik akan mempengaruhi tatanan dunia secara global.

Lebih jauh, Holsti (1988) pernah mengemukakan bahwa hingga saat ini negara-negara berkembang memiliki makna politis penting bagi negara demokrasi maju. Pembangunan ekonomi yang baik merupakan harapan besar bagi tercapainya kemajuan demokrasi di negara berkembang. Sementara, instabilitas politik dan kemelaratan ekonomi secara langsung maupun tidak langsung akan dapat menimbulkan ancaman keamanan internasional dan kondisi yang dapat dimanfaatkan oleh rezim komunis. Oleh sebab itu, kosmopolitanisme demokrasi mencapai tahap di mana konsep kerja sama pembangunan internasional menginternalisasi struktur institusional yang paling diminati yaitu good governance.

Dalam lingkup domestik negara-negara perlu proses untuk menyesuaikan diri dengan perubahan unit-unit ekonomi-politik internasional yang begitu cepat. Sementara, proses penyesuaian struktural -good governance- tersebut secara internal perlu melalui sosialisasi, edukasi, dan pemberdayaan pemangku kebijakan. Di sinilah peran bantuan teknis dari negara donor dibutuhkan sebagai 'source of agent' atau fasilitator yang membantu pemerintah dalam implementasi kesepakatan internasional tanpa dibebani oleh kebergantungan finansial.

Bagaimanapun, kerja sama pembangunan dan upaya 
pemberantasan kemiskinan merupakan kepentingan bersama. Sehingga, kemitraan strategis baik secara internal maupun internasional penting untuk ditingkatkan.

\section{CATATAN AKHIR}

1 Checkel menulis, "Indeed, a hallmark of corporatism is the policy networks connecting state and society, with the latter still accorded an important role in decision-making. In this setting, it is both societal pressure (primary) and elite learning (secondary) that lead to norm empowerment". Pendapat ini didukung dengan realitas di Indonesia yang mengakui kebebasan pers sejak diberlakukannya Undang-Undang Nomor 40 Tahun 1999 Tentang Pers dan dilaksanakannya pemilihan langsung Presiden sejak tahun 2004. Indonesia juga tercatat sebagai salah satu negara demokratis. Selengkapnya baca <http://www.dewanpers.org/

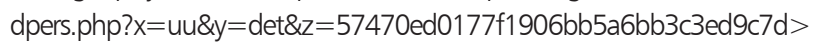
dan <http://www.freedomhouse.org/sites/default/files/ WorstOfTheWorst2011.pdf>

2 Kerja sama pembangunan internasional diyakini sebagai upaya menciptakan tatanan dunia yang lebih maju dan sejahtera. Pembangunan dianggap mampu menjembatani kesenjangan antara negara maju dan negara sedang berkembang yang dikenal dengan 'fenomena Utara-Selatan'. Krisis ekonomi Eropa (Great Depression) tahun 1930-an menjadi titik tolak dipromosikannya kerja sama pembangunan internasional yang memanfaatkan pinjaman luar negeri. Amerika Serikat (AS) membantu rekonstruksi Eropa melalui kebijakan Marshal Plan 1947. Lebih jauh, kerja sama pembangunan internasional diperkuat dengan lahirnya IMF dan Bank Dunia.

3 Bureaupathologies meliputi penilaian terhadap pemerintahan yang kurang memiliki kemampuan untuk memenuhi tuntutan masyarakat dan merespon perkembangan situasi baik di dalam maupun luar negeri. Lembaga legislatif yang seharusnya memperjuangkan aspirasi rakyat tidak memiliki komitmen dan mudah dikooptasi oleh kelompok kepentingan tertentu. Sementara, lembaga yudikatif yang berperan dalam penegakan hukum tidak memiliki wibawa dan dapat 'dibeli' oleh pihak-pihak yang berkuasa.

4 Good governance adalah sistem kelembagaan yang diinginkan oleh Bank Dunia. "'Good governance," a term that came into vogue in the 1990s with the World Bank leading the charge, has assumed the status of a mantra for donor agencies as well as donor countries for conditioning aid upon the performance of the recipient government. This is intended to ensure that the development assistance is used effectively"

5 Berdasarkan data yang diteliti pada tahun 1970-1994, Alesia dan Dollar menyatakan "Thus, a positive coefficient indicates a positive relationship between democracy and aid. More open and more democratic countries receive more aid."

6 Pencapaian target MDGs direalisasikan melalui kerjasama dengan institusi-intitusi global seperti United Nations Development Programme (UNDP), Millenium Campaign, UN Department of Economic \& Social Affairs (UNDESA), World Bank, UN Children's Fund (UNICEF), UN Environment Programme (UNEP), UN Population Fund (UNFPA), World Health Organization (WHO),
International Monetary Fund (IMF), UN Human Settlements Programme (UN-HABITAT), Food \& Agriculture Development (FAO), International Fund for Agricultural Development (IFAD), International Labour Organization (ILO), International Telecommunication Union (ITU), Joint UN Programme on HIV/AIDS (UNAIDS), UN Conference on Trade and Development (UNCTAD), UN Development Group (UNDG), UN Educational, Scientific, and Cultural Organization (UNESCO), UN Refugee Agency (UNHCR), UN Industrial Development Organization (UNIDO), UN Entity for Gender Equality and the Empowerment of Woman (UN Women), Office of the High Commisioner for Human Right (OHCHR), UN Relief and Works Agency for Palestine Refugees in the Near East (UNRWA), World Food Programme (WFP), World Meteorological Organization (WMO), World Trade Organization (WTO), UN World Tourism Organization (UNWTO) dan UN Office on Sport for Development and Peace (UNOSDP). Keterangan selengkapnya pada $<$ http://www.un.org/millenniumgoals/>

7 Hubungan perdagangan Indonesia-Jerman telah dimulai sejak abad ke 19. Setelah berakhirnya Perang Dunia II dan setelah Proklamasi Republik Indonesia, pada tahun 1949 banyak mahasiswa Indonesia melanjutkan studi di Jerman. Para lulusan jerman, dengan keahlian yang mereka dapat di Jerman sekembalianya ke Indonesia menyumbangkan keahliannya bagi pembangunan Indonesia yang baru berdiri. Hubungan diplomatik yang resmi antara Republik Federal Jerman dan Republik Indonesia yang sudah merdeka, dibuka pada tahun 1952. Pada tahun yang sama dibuka Kedutaan Besar Republik Federal Jerman di Jakarta. Sejak itu kerja sama antar kedua negara terus meningkat. Sekarang tidak kurang dari 250 perusahaan Jerman membuka cabang di Indonesia. Kerja sama di bidang pembangunan ekonomi dan bidang ilmu pengetahuan dan teknik memainkan peranan yang penting. Sumber: "Sejarah Hubungan Jerman-Indonesia", < http://www.jakarta.diplo.de/ Vertretung/jakarta/id/03/Bilaterale_Beziehungen/ seite_geschichte_beziehungen. $\mathrm{html}>$

8 Harold Lasswell, Politics: Who Gets What, When and How (Cleveland and New York: World, 1958)

\section{REFERENSI}

Aid Effectiveness Portal 2009, Jakarta Commitment: Aid for Development Effectiveness Indonesia's Road Map to 2014, diunduh 12 Desember 2011 pada < http://www.aideffectiveness.org/Tools/AidManagement/Action-Plans/Jakarta-Commitment-on-AidEffectiveness.html>

Aid for Development Effectivenes Secretariat (A4DES), Jakarta Commitment: Aid for Development Effectiveness Indonesia's Road Map to 2014, diunduh 29 Oktober 2011 pada < http:// a4des.org/documents/Jakarta\%20Commitment.pdf >

Alesina, Alberto dan David Dollar 2000, "Who Gives Foreign Aid to Whom and Why?", Journal of Economic Growth, Vol. 5, No. 1 (Mar., 2000), pp.33-63, Springer, diunduh 17 Maret 2012 pada $<$ http://www.jstor.org.ezproxy.ugm.ac.id/stable/pdfplus/ 40216022.pdf>

Altmann, Joern, et. al., 2000, "The UNDP Role in Decentralization and Local Governance: A Joint UNDP-Government of Germany Evaluation", Evaluation Team on 28 February 2000, UNDP and 
German Federal Ministry for Economic Cooperation and Development (BMZ), diunduh 19 September 2012 pada <http:// web.undp.org/evaluation/documents/ decentralization_final_Report.PDF>

Anghie, Antony, 2004, "International Financial Institutions", The Politics of International Law, Christian Reus-Smit (ed.), Cambridge University Press, New York.

Antara 2011, berita 14 Juni 2011 berjudul "WTO Pertahankan Bantuan Perdagangan Bagi Negara Berkembang", diunduh 24 Mei 2012 pada < http://id.berita.yahoo.com/wto-pertahankan-bantuanperdagangan-bagi-negara-berkembang-133747071.html>

Arief, Sritua, 1996, “Negara-negara Berkembang. Hutang Luar Negeri dan Kebijaksanaan Bank Dunia / IMF", Jayadi Damanik, dkk. (eds.), Membangun di Tengah Pusaran Hutang : Tinjauan Multidisipliner Hutang Luar Negeri dan Pembangunan Indonesia, INTERFIDEI, Yogyakarta.

Aryani, Desy, 2006, "Dilema Pembangunan Indonesia dalam Jerat Hutang Kapitalisme", S. Djuni Prihatin, dkk. (eds.) Pembangunan dan Kemiskinan, Aditya Media dan Jurusan Sosiatri Fisipol Universitas Gadjah Mada, Yogyakarta.

Aspinall, Edward, Herbert Feith, dan Gerry van Klinken (eds.), 2000, Titik Tolak Reformasi: Hari-hari Terakhir Presiden Soeharto, LKiS, Yogyakarta.

Badan Pusat Statistik 2012, "Kemiskinan", Sosial dan Kependudukan, diunduh 14 September 2012 pada:

$<$ http://www.bps.go.id/tab_sub/ view.php? kat $=1 \&$ tabel $=1 \&$ daftar $=1$ \&id_subyek $=23 \&$ notab $=1>$

Bappenas 2008, “UU No. 32 Tahun 2004 Tentang Pemerintahan Daerah", Undang-Undang, Publikasi Bappenas 20 November 2008, diunduh 6 Mei 2012 pada < http://www.bappenas.go.id/node/123/ 19/uu-no-32-tahun-2004-tentang-pemerintahan-daerah-/>

Bappenas 2009, 'Langkah Strategis Dalam Kerjasama Pembangunan: Jakarta Commitment Ditandatangani', laporan 13 Januari 2009, Kementrian Perencanaan Pembangunan Nasional, diunduh 29 Oktober 2011 pada <http://www.bappenas.go.id/node/116/1682/ langkah-strategis-dalam-kerja-sama-pembangunan-jakartacommitment-ditandatangani/>

Bappenas 2010, 'Ulang Tahun Pertama Jakarta Commitment', Iaporan 8 Februari 2010, Kementrian Perencanaan Pembangunan Nasional, diunduh 19 Oktober 2011 pada <http://www.bappenas.go.id/ node/116/2519/ulang-tahun-pertama-jakarta-commitment/>

Barkin, J. Samuel, 2006, "Sovereignty and Globalization", International Organization: Theories and Institutions, Palgrave Macmillan, New York.

Baylis, John dan Steve Smith, 2001, The Globalization on World Politics: An Introduction to International Relations, Edisi Ketiga, Oxford University Press, Inc., United States.

Behrens, Cristoph, 2008-2010, "We could meet with Modernity", Public Administration Reform and Good Governance in Yogyakarta, Report on the Assignment of Dr. Christoph Behrens Integrated Expert 2008-2010 at Pemprov DIY, diunduh 28 Oktober 2011 pada:

< http://drchristophbehrens.files.wordpress.com/2010/08/ finalreportfirstassignmentperiod150910.pdf>

Bell, Judith, 2010, "The grounded theory approach", Doing Your Research Project, Fifth Edition, Open University Press, McGraw-Hill
Education, England

BKPM Pemprov DIY, n.d., "Proses Pelayanan Perizinan Penanaman Modal", Badan Kerjasama dan Penanaman Modal Pemerintah Provinsi D/Y, diunduh 19 September 2012 pada < http:// bkpm.jogjaprov.go.id/index.php/perijinan/lists>

Burchil, Scott, et al., 2005, Theories of International Relations, Edisi Ketiga, Palgrave Macmillan, New York.

Buzan, Barry dan Lene Hansen, 2009, "Widening and Deepening Security", The Evolution of International Security Studies, Cambridge University Press, New York.

CGG Indo (a), n.d., "Desain Proses Reformasi", Konsultasi: Reformasi Administrasi dan Manajemen SDM, diunduh 10 Juli 2012 pada $<$ http://cggindo.wordpress.com/yang-kami-lakukan/administrativereform/desain-proses-reformasi/>

CGG Indo (b), n.d., "Monitoring dan Evaluasi", Konsultasi, diunduh 10 Juli 2012 pada < http://cggindo.wordpress.com/yang-kami-lakukan/ monitoring-dan-evaluasi/>

CGG Indo (c), n.d., "Penilaian Kepemerintahan DPRD", Konsultasi: Monitoring dan Evaluasi, diunduh 10 Juli 2012 pada <http:// cggindo.wordpress.com/yang-kami-lakukan/monitoring-danevaluasi/penilaian-kepemerintahan/>

Checkel, Jeffrey T., 1997, "International Norms and Domestic Politics: Bridging the Rationalist-Constructivist Divide", European Journal of International Relations 1997; 3; 473-495, Sage Publications, $<$ http://ejt.sagepub.com/cgi/content/abstract/3/4/473>

Cohen, Jeffrey P. 2008, Agglomeration, Productivity, and Regional Growth: Production Theory Approaches, diunduh 10 September pada <http://www.distillate.ac.uk/outputs/ Deliverable\%20C2\%20v6.0.pdf>

Coplin, William D., 1992, Marsedes Marbun (terj.), Pengantar Politik Internasional: Suatu Telaah Teoritis, Edisi Kedua, Sinar Baru, Bandung.

Coplin, William D., 2003, Pengantar Politik Internasional: Suatu Telaah Teoritis, Mersedes Marbun (ed.), Penerbit Sinar Baru, Bandung.

Daniel, Wahyu, 'RI Teken Jakarta Commitment' Untuk Kemandirian Kelola Utang', Detik Finance, laporan 13 Januari 2009, diunduh 19 Oktober 2011 pada < http://finance.detik.com/read/2009/01/13/ 065225/1067290/4/ri-teken-jakarta-commitment-untukkemandirian-kelola-utang $>$

Data Strategis BPS 2012. Badan Pusat Statistik, Diunduh 14 September 2012 pada < http://www.bps.go.id/aboutus. php?65tahun=1>

Deplu, 2003, Sekilas WTO: World Trade Organization, Direktorat Perdagangan dan Perindustrian Multilateral, Direktorat Jenderal Multilateral Ekonomi, Keuangan, dan Pembangunan, Departmen Luar Negeri, Jakarta.

Dewan Pers 2006a, “Undang-Undang Nomor 40 Tahun 1999 Tentang Pers", Undang-Undang, diunduh pada 11 Maret 2012 pada:

$<$ http://www.dewanpers.org/ dpers.php? $x=u$ u \&y $=$ det\&z= 57470ed0177f1906bb5a6bb3c3ed9c7d $>$

Dewan Pers 2006b, n.d., "Undang-Undang Nomor 40 Tahun 1999 tentang Pers", Undang-Undang, diunduh 11 Maret 2012 pada: $<$ http://www.dewanpers.org/ dpers.php? $x=u$ u \&y $=$ det\&z $=57470$ ed $0177 f 1906 b b 5 a 6 b b 3 c 3 e d 9 c 7 d>$

Dinas Perizinan 2012, "Sejarah Dinas Perizinan", Pemerintah Kota Yogyakarta, diunduh 14 September 2012 pada: $<$ http://perizinan.jogjakota.go.id/ 
home. php? mode $=$ content\&id $=181>$

Direktorat Jenderal Pengelolaan Utang, n.d., "Peraturan Pemerintah Republik Indonesia Nomor 10 Tahun 2011 Tentang Tata Cara Pengadaan Pinjaman Luar Negeri dan Penerimaan Hibah", Peraturan, Kementerian Keuangan Republik Indonesia, diunduh 9 Juli 2012 pada:

$<$ http://www.dmo.or.id/dmodata/4Peraturan_dan_Ketentuan/ 2Peraturan_Pemerintah/PP 10_2011_Tata\%20Cara\%20Penerimaan\%20PLN\%20dan\%20Hibah\%20LN/PP 102011 Tata\%20Cara\%20PLN\%20dan\%20Penerimaan\%20Hibah.pdf>

Ditjen Otda Depdagri, n.d., Peraturan Pemerintah Republik Indonesia Nomor 45 Tahun 1992 Tentang Penyelenggaraan Otonomi Daerah Dengan Titik Berat Pada Daerah Tingkat II, diunduh 6 Juli 2012 pada < http://www.ditjen-otda.depdagri.go.id/otdaiii/pp-451992.pdf>

Dugaard, Morten dan Richard Higgott (eds.), 2002, Towards a Global Polity, Roudledge, New York.

Dwiyanto, Agus, dkk., 2003, Reformasi Tata Pemerintahan dan Otonomi Daerah, Pusat Studi Kependudukan dan Kebijakan (PSKK) Universitas Gadjah Mada, Yogyakarta.

Fatwa, A.M., 2004, Melanjutkan Reformasi Membangun Demokrasi: Jejak Langkah Parlemen Indonesia Periode 1999-2004, PT. Raja Grafindo, Jakarta.

Ferrazzi, Gabriele, dan Rainer Rohdewohld, “Decentralization Reform and Development Cooperation - Reflections on the Result of German Technical Cooperation Supporting Decentralization Reforms in Indonesia (1992-2010)", makalah disampaikan dalam Konferensi 10 tahun Desentralisasi di Asia Tenggara, Universitas Freiburg, Jerman, tanggal 15 - 17 Juni 2011. Pustaka GIZ JakartaIndonesia.

Finnemore, Martha dan Kathryn Sikkink 2001, "Taking Stock: The Constructivist Research Program in International Relations and Comparative Politics", Annual Review of Political Sciences, 2001, 4: 391-416, diunduh 5 Januari 2012 pada < http:// www.rochelleterman.com/ir/sites/default/files/ finnemore\%20and\%20sikkink\%202002.pdf>

Folke, Steen dan Henrik Nielsen (eds.), 2006, Aid Impact and Poverty Reduction, Palgrave Macmillan, New York.

Hanik, Umi dan Heru Subiyantoro 2011, "Monitoring \& Evaluasi Sebagai Konsensus Untuk Mencapai Efektivitas Pemanfaatan Pinjaman/Hibah Luar Negeri", publikasi 9 Januari 2011, diunduh 24 Desember 2011 pada:

$<$ http://www.slideshare.net/umihanik/me-sebagai-konsensus-untukefektivitas-pemanfaatan-phln>

Harinowo, Cyrillus, 2002, Utang Pemerintah: Perkembangan, Prospek dan Pengelolaannya, PT. Gramedia Pustaka Utama, Jakarta.

Held, David, 1995, Democracy and the Global Order: From the Modern State to Cosmopolitan Governance, Stanford University Press, California.

Hittipeuw, Jimmy 2012, "Bisnis Media Cetak Masih Berpeluang", Kompas 28 Januari 2012, diunduh 4 Mei 2012 pada: <http://bisniskeuangan.kompas.com/read/2012/01/28/05493874/ Bisnis.Media.Cetak.Masih.Berpeluang >

Holsti, K.J., 1988, M. Tahir Azhari (Terj.), Politik Internasional: Kerangka Untuk Analisis, Edisi Keempat, Jilid I, Penerbit Erlangga, Jakarta.

Hutington, Samuel P., 1990, The Third Wave: Democratization in the
Late Twentieth Century, University of Oklahoma Press, Norman and London.

IMF 2005, "The IMF's Approach to Promoting Good Governance and Combating Corruption - A Guide", publikasi 20 Juni 2005, The International Monetary Fund, diunduh 19 Maret 2012 pada:

<http://www.imf.org/external/np/gov/guide/eng/index.htm>

Investor Daily 2011, berita 15 Juni 2011 berjudul "WTO Pertahankan

Bantuan Perdagangan Bagi Negara Berkembang", diunduh 22 Mei 2012 pada <http://www.investor.co.id/home/wto-pertahankanbantuan-perdagangan-bagi-negara-berkembang/14053>

Jackson, Robert dan Georg Sorensen, 1999, Introduction to International Relations, Oxford University Press, Inc., New York.

JICA, n.d., Participatory Development and Good Governance Report of The Aid Study Committee, Publications, Topical and Sectoral Studies, Summary, Japan International Cooperation Agency (JICA), diunduh 17 Maret 2012 pada <http://www.jica.go.jp/english/ publications/reports/study/topical/part/part_2.html>

Keban, Yeremias T., 2000, "Good Governance" dan "Capacity Building" sebagai Indikator Utama dan Fokus Penilaian Kinerja Pemerintahan, Naskah No. 20, Juni-Juli 2000, diunduh 19 September 2012 pada < www.bappenas.go.id/get-file-server/node/ 8635/>

Kedutaan Besar Jerman Jakarta, n.d., "Institusi-institusi dari bidang kerja sama pembangunan di Indonesia", Deutsche Botschaft Jakarta, diunduh pada 29 Desember 2011 pada:

< http://www.jakarta.diplo.de/Nertretung/jakarta/id/05/ Wirtschaftliche_Zusammenarbeit/inst_gastland_wz.html>

Kedutaan Besar Jerman Jakarta, n.d., "Sejarah Hubungan JermanIndonesia", Home, diunduh 4 Juli 2012 pada:

< http://www.jakarta.diplo.de/Nertretung/jakarta/id/03/

Bilaterale_Beziehungen/seite_geschichte_beziehungen.html>

Kementerian Energi dan Sumber Daya Mineral, $\bar{n}$. d., "Undang-Undang Nomor 28 Tahun 1999 tentang Penyelenggaraan Negara yang Bersih dan Bebas dari Korupsi, Kolusi dan Nepotisme", Presiden Republik Indonesia, diunduh 16 April 2012 pada < http:// prokum.esdm.go.id/uu/1999/uu-28-1999.pdf>

Kementerian Energi dan Sumber Daya Mineral, Undang-Undang Republik Indonesia Nomor 22 Tahun 1999 Tentang Pemerintahan Daerah, diunduh 26 April 2012 pada < http://prokum.esdm.go.id/ uu/1999/uu-22-1999.pdf>

Kementerian Pekerjaan Umum Republik Indonesia, n.d., "Ketetapan MPR RI Nomor XI/MPR/1998 tentang Penyelenggaraan Negara yang Bersih dan Bebas Korupsi, Kolusi dan Nepotisme", Majelis Permusyawaratan Rakyat Republik Indonesia, diunduh 16 April 2012 pada:

$<$ http://www.pu.go.id/satminkal/itjen/hukum/tmpr11-98.htm>

Kemitraan, n.d., "Misi dan Visi", Partnership for Governance Reform, diunduh 15 September 2012 pada < http://www.kemitraan.or.id/ main_ind/content2/21/22>

Kemitraan, n.d., "Sejarah Singkat", Partnership for Governance Reform, diunduh 15 September 2012 pada < http:// www.kemitraan.or.id/main ind/content2/21/25>

Kemitraan, n.d., "Tanya Kami", Partnership for Governance Reform, diunduh 15 September 2012 pada < http://www.kemitraan.or.id/ main_ind/faq $>$

Kemlu RI 2009a, "Dasar Hukum Politik Luar Negeri", Beranda: 
Landasan, Visi, Misi, Polugri, Kementrian Luar Negeri Republik Indonesia, diunduh 29 Oktober 2011 pada <http:// www.kemlu.go.id/Pages/Polugri.aspx?l=id > ,

Kemlu RI 2009b, Isu-Isu Khusus, "Pencapaian MDGs", Kementerian Luar Negeri Republik Indonesia, Rilis berita 5 September 2009, diunduh 23 April 2012 pada <http://www.kemlu.go.id/Pages/ IlssueDisplay.aspx?|DP=8\&|=id $>$

Kemlu RI 2009c, State of Play Perundingan Doha Development Agenda (DDA) dan Isu-isu Reguler WTO, Jenewa, 28 Januari 2009, Pernyataan Kementerian Luar Negeri Indonesia yang dirilis 17 Maret 2011, diunduh 24 Mei 2012 pada <http://www.kemlu.go.id/ ptri_temp/Pages/Statement.aspx?IDP=1\&IDP2=6\&l=id >

Keohane, Robert O., "International Institutions: Two Approaches" dalam Friedrich Kratochwil dan Edward D. Mansfield, 1994, International Organization; A Reader, HarperCollins College Publishers, New York.

Khoiriati, Siti Daulah et al., 2010, Bantuan Luar Negeri dan Pembangunan Ekonomi di Negara Berkembang: Analisis Perbandingan Motif dan Implikasi Kebijakan Bantuan Luar Negeri Amerika Serikat ke Cile (1970-1980) dan Jepang ke Indonesia (1970-1990), Laporan Riset Kolaborasi Dosen-Mahasiswa, Jurusan Hubungan Internasional, Universitas Gadjah Mada, Yogyakarta.

Kimmet, Philip, 2004, The Politic of Good Governance in The ASEAN 4, Pustaka Deutsche Gesellschaft fur Internationale Zusammenarbeit (GIZ), Jakarta.

Kompas 2012, Agung, S. Laksana, "Yogyakarta Terbaik dalam Iklim Investasi", Regional, Kompas 31 Januari 2012, diunduh 15 September 2012 pada < http://regional.kompas.com/read/2012/01/ 31/11210032/Yogyakarta.Terbaik.dalam.Iklim.Investasi>

KPK 2006, Kumpulan Undang Undang Pemberantasan Tindak Pidana Korupsi, Edisi Pertama, diunduh pada 15 Desember 2011 pada:

$<$ www.kpk.go.id/modules/edito/doc/kumpulan_uu.pdf >

KPK, n.d., Undang-Undang Pendukung, Komisi Pemberantasan Korupsi, diunduh 16 April 2012 pada <http://www.kpk.go.id/modules/edito/ content.php?id $=5>$

Krina P., Loina Lalolo, 2003, Indikator dan Alat Ukur Prinsip Akuntabilitas, Transparansi dan Partisipasi, Sekretariat Good Public Governance, Badan Perencanaan Pembangunan Nasional, Agustus 2003, diunduh 19 September pada: < http:// goodgovernance.bappenas.go.id/gg/file/concept/ good_governance.pdf $>$

Kuhnen, Frithjof, 1986, 1987, “Causes Underdevelopment and Concepts for Development: An Introduction to Development Theories", The Journal of Institute of Development Studies, NWFP Agricultural Vol.VIII, Peshawar University.

Kuncoro, Mudrajad, 2004, Otonomi \& Pembangunan Daerah: Reformasi, Perencanaan, Strategi, dan Peluang, Penerbit Erlangga, Jakarta.

Lane, Max, 2004, 'Re-organisation' of Mass Politics and the Weakened National Revolution in the Era of Neo-Liberal Globalisation, Working Paper No.102, January 2004, Asia Research Centre, Murdoch University, National Library of Australia, diunduh 9 Maret 2012 pada:

<http://wwwarc.murdoch.edu.au/publications/wp/WP102.pdf>

Legowo, Satya 2012, "Anggota LOD - LOS DIY Masa Jabatan 2012 2015 Dikukuhkan", Pemerintah Propinsi DIY, Publikasi Berita 10
Januari 2012, diunduh 6 Juni 2012 pada:

$<$ http://portal.jogjaprov.go.id/

index.php?option=com_content\&view=article\&id =498:anggota-

lod-los-diy-masa-jabatan-2012-2015-

dikukuhkan\&catid $=48$ : berita-pemerintah >

Leifer, Michael, 1986, Politik Luar Negeri Indonesia, PT. Gramedia, Jakarta.

Maclntyre, Andrew, 1994, Organising Interests: Corporatism in Indonesian Politics, Working Paper No.43, August 1994, Asia Research Centre, Murdoch University, National Library of Australia, diunduh 9 Maret 2012 pada <http://wwwarc.murdoch.edu.au/ publications/wp/WP43.pdf $>$

Mas'oed, Mohtar, 1998, Perdagangan Dalam Perspektif EkonomiPolitik Internasional, Universitas Gadjah Mada, Yogyakarta.

Mas'oed, Mohtar, 2008, Politik, Birokrasi, dan Pembangunan, Pustaka Pelajar, Yogyakarta

Mingst, Karen, 1999, Essentials of International Relations, W.W. Norton \& Company, Inc., United States.

Mkandawire, Thandike 2007, "'Good Governance': The Itinerary of an Idea", Development in Practice, Vol. 17, No. 4/5 (Aug., 2007), pp.679-681, Taylor \& Francis, Ltd., diunduh 17 Maret 2012 pada:

$<$ http://www.jstor.org.ezproxy.ugm.ac.id/stable/pdfplus/ 25548269.pdf>

Mugasejati, Nanang Pamuji dan Ahmad Hanafi Rais, 2011, Politik Kerjasama Internasional: Sebuah Pengantar, IIS Monograph Series, Institute of International Studies (IIS) Jurusan IImu Hubungan Internasional, Fakultas IImu Sosial dan IImu Politik, Universitas Gadjah Mada, Yogyakarta.

Musianto, Lukas S., 2004, “Perbedaan Pendekatan Kualitatif dengan Pendekatan Kuantitatif dalam Metode Penelitian", Jurnal Manajemen \& Kewirausahaan, Vol. 4, No.2, pp.123-136, diterbitkan September 2002, diunduh 10 Desember 2011 pada $<$ puslit.petra.ac.id/journals/ pdf.php?PublishedID=MAN02040206>

Nanda, Ved P. 2006, "The "Good Governance" Concept Revisited", Annals of the American Academy of Political and Social Science, Vol. 603, Law, Society, and Democracy: Comparative Perspectives (Jan., 2006), pp.269-283, Sage Publications, Inc. \& American Academy of Political and Social Science, diunduh 17 Maret 2012 pada:

$<$ http://www.jstor.org.ezproxy.ugm.ac.id/stable/pdfplus/ 25097772.pdf?acceptTC = true>

OECD 2002, "Technical Co-operation", Definition, Glossary of Statistical Terms, diunduh 10 Juli 2012 pada < http://stats.oecd.org/glossary/ detail.asp? |D=2686>

OECDa, n.d., "Principal elements of good governance", Directorate for Public Governance and Territorial Development, diunduh 10 Juli 2012 pada:

$<$ http://www.oecd.org/document/32/ 0,3746,en_2649_33735_1814560_1_1_1_1,00.html>

$\mathrm{OECDb}$, n.d., "Paris Declaration and Accra Agenda for Action", Development Co-operation Directorate (DCD-DAC): Aid Effectiveness, diunduh 9 Juli 2012 pada <http://www.oecd.org/ document/18/ 0,3746,en_2649_3236398_35401554_1_1_1_1,00.html> OECDc, n.d., "Countries, Territories and Organisations Adhering to the 
Paris Declaration and AAA", Development Co-operation Directorate (DCD-DAC): Aid Effectiveness, diunduh 9 Juli 2012 pada:

$<$ http://www.oecd.org/document/22/

0,3746,en_2649_3236398_36074966_1_1_1_1,00.html>

Payer, Cheryl, 1974, The Debt Trap: The IMF and the Third World, Penguin Books, Great Britain.

Pemerintah Kota Yogyakarta 2008, "Kota Jogja Raih Penghargaan

Tingkat Nasional Bidang Pelayanan Terpadu", Berita 7 Januari 2008

Unit Pelayanan Informasi dan Keluhan Pemerintah Kota

Yogyakarta, diunduh 19 September 2012 pada <http://

upik.jogjakota.go.id/news/

index.cfm? berita id $=07012008133527 \& x=2>$

Piano, Aili, et al, (eds.), 2011, "Worst of the Worst 2011, The World's Most Repressive Societies", Freedom in the World 2011, Freedom House's Annual Global Survey of Political Rights and Civil Liberties, diunduh 11 Maret 2012 pada <http://www.freedomhouse.org/ sites/default/files/WorstOfTheWorst2011.pdf>

Punyaratabandhu, Suchitra, 2004, "Commitment to good governance, development and poverty reduction : methodological issues in the evaluation of progress at the national and local levels", CDP Background Paper No.4 ST/ESA/2004/CDP/4, Economic and Social Affairs, diunduh 19 September 2012 pada < https://www.un.org/ en/development/desa/policy/.../bp2004_4.pdf>

Rais, Mohammad Amien 2008, Agenda Mendesak Bangsa: Selamatkan Indonesia!, Penerbit PPSK Press, Yogyakarta.

Reus-Smit, Christian (ed.), 2004, The Politics of International Law, Cambridge University Press, New York.

Sedarmayanti, 2003, Good Governance Dalam Rangka Otonomi Daerah, Mandar Maju, Bandung.

Siregar, Muchtarudin 1990, Pinjaman Luar Negeri \& Pembiayaan Pembangunan Indonesia, Lembaga Penerbit Fakultas Ekonomi Universitas Indonesia, Jakarta.

Skrbis, Zlatko, Gavin Kendall and lan Woodward, 2004, “Locating Cosmopolitanism between Humanist Ideal and Grounded Social Category", Theory, Culture \& Society, Sage Journals Online, diunduh 5 Januari 2012 pada <http://tcs.sagepub.com/cgi/ content/refs/21/6/115>

Sterling-Folker, Jennifer, 2006, Making Sense of International Relations Theory, Lynne Rienner Publishers, Inc., London.

Suara Karya 2005, berita 14 Desember 2005 berjudul "Perundingan WTO: Negara Maju Janjikan Hibah", diunduh 24 Mei 2012 pada $<$ http://www.suarakarya-online.com/news.html?id=129771>

Sulistiyani, Ambar Teguh (ed.), 2011, Memahami Good Governance Dalam Perspektif Sumber Daya Manusia, Gava Media, Yogyakarta.

Syakrani dan Syahriani, 2009, Implementasi Otonomi Daerah dalam Perspektif Good Governance, Pustaka Pelajar, Yogyakarta.

Tender-Indonesia.com 2010, "Indonesia terima hibah dari Jerman US\$ 37,5 Juta", Berita Keuangan 12 Mei 2010, diunduh 4 Juli 2012 pada < http://www.tender-indonesia.com/tender home/ innerNews2. php?id $=5446 \&$ cat $=$ CT0013>

Tjokrowinoto, Moeljarto, 1996, Pembangunan: Dilema dan Tantangan, Pustaka Pelajar, Yogyakarta.

Topatimasang, Roem, 1999, "Jerat Hutang Luar Negeri", Kejahatan Hutang Luar Negeri dan Reformasi Bank Dunia, WACANA, Jurnal IImu Sosial Transformatif. No. III. pp. 2-17.

UNDP (a), n.d., "Human Development Report 1993: People's Participa- tion", Human Development Reports, United Nations Development Programme, diunduh 8 Juni 2012 pada < http://hdr.undp.org/en/ reports/global/hdr1993/>

UNDP (b), n.d., "Human Development Report 1994: New Dimensions of Human Security", Human Development Reports, United Nations Development Programme, diunduh 8 Juni 2012 pada:

$<$ http://hdr.undp.org/en/reports/global/hdr1994/>

UNDP (c), n.d., "The Human Development Report", Human Development Reports, United Nations Development Programme, diunduh 8 Juni 2012 pada:

<http://hdr.undp.org/en/reports/about/>

UNDP 1997, "Governance for sustainable human development:

A UNDP policy document", United Nations Development Programme diunduh 19 September 2012 pada:

$<$ http://mirror.undp.org/magnet/policy/summary.htm>

UNDP 2011, "Why Good Governance Makes for Better Development", Publikasi 12 Mei 2011, Our Perspective, United Nations Development Programme, diunduh 8 Juni 2012 pada:

$<$ http://www.undp.org/content/undp/en/home/ourperspective/ ourperspectivearticles/2011/05/20/why-good-governance-makesfor-better-development.html>

UNDP 2012a, "A Wold of Development Experience", About us, United Nations Development Programme, diunduh 8 Juni 2012 pada:

$<$ http://www.undp.org/content/undp/en/home/operations/about_us/ $>$

UNDP 2012b, "Democratic Governance", Our Work, United Nations Development Programme, diunduh 8 Juni 2012 pada:

$<$ http://www.undp.org/content/undp/en/home/ourwork/ democraticgovernance/overview.html>

UNDP 2012c, "MDG Strategies", Focus Areas, United Nations Development Programme, diunduh 8 Juni 2012 pada:

$<$ http://www.undp.org/content/undp/en/home/ourwork/ povertyreduction/focus_areas/focus_mdg_strategies/>

UNDP Indonesia, n.d., Millenium Development Goals, United Nations Development Programme Indonesia, diunduh 19 Oktober 2011 pada < http://www.undp.or.id/mdg/>

UNESCAP 2011, What is good governance?, United Nations Economic and Social Commission for Asia and the Pasific, diunduh 15 Desember 2011 pada < http://www.unescap.org/pdd/prs/ ProjectActivities/Ongoing/gg/governance.asp>

United Nations 2010, "A Gateway to the UN System's Work on the MDGs", United Nations Department of Public Information, diunduh 25 April 2012 pada <http://www.un.org/millenniumgoals/ $>$

United Nations, 2007, Good Governance Practices for The Protection of Human Rights, Office of The United Nations High Commissioner for Human Rights, United Nations Publication, Switzerland.

United Nations, n.d., "Development", Global Issues, diunduh 8 Juni 2012 pada < http://www.un.org/en/globalissues/development/ index.shtml $>$

UNSRAT 2004, Draf UU 25 Tahun 2004, diunduh 29 Oktober 2011 pada <http://hukum.unsrat.ac.id/uu/uu 25 04.htm>

Viotti, Paul R. dan Mark V. Kauppi, 2009, International Relations and World Politics: Security, Economy, Indentity, Edisi Keempat, Pearson Education International, New Jersey.

Wijaya, Sastra 2010, "Media Cetak Bersaing dengan Internet", BBC 13 
Maret 2010, diunduh 4 Mei 2012 pada

<http://www.bbc.co.uk/indonesia/laporan_khusus/2010/03/

100312 mediainternet.shtml>

Winarno, Budi, 2010, "Telaah Kritis Agenda Good Governance", Melawan Gurita Neoliberalisme, Erlangga, Jakarta.

Winham, Gilbert R., 2005, 'The Evolution of The Global Trade Regime', Global Political Economy, John Ravenhill (ed.), Oxford University Press, New York.

World Bank 2011, "Governance \& Anticorruption", Overview, diunduh 9 September 2012 pada:

<http://web.worldbank.org/WBSITE/EXTERNAL/TOPICS/EXTGO-

VANTICORR/0,,contentMDK:22675075 menuPK:7430-

607 pagePK:210058 piPK:210062 theSitePK:3035864,00.html> 